\begin{tabular}{|l|l|l||}
\hline \multicolumn{2}{|c|}{ PublisherInfo } \\
\hline \hline PublisherName & $:$ & BioMed Central \\
\hline \hline PublisherLocation & $:$ & London \\
\hline \hline PublisherImprintName & $:$ & BioMed Central \\
\hline \hline
\end{tabular}

\title{
Selective remodelling
}

\begin{tabular}{|l|l|l||}
\hline \multicolumn{2}{|c|}{ ArticleInfo } \\
\hline \hline ArticleID & $:$ & 3810 \\
\hline \hline ArticleDOI & $:$ & $10.1186 /$ gb-spotlight-20001025-02 \\
\hline \hline ArticleCitationID & $:$ & spotlight-20001025-02 \\
\hline \hline ArticleSequenceNumber & $:$ & 247 \\
\hline \hline ArticleCategory & $:$ & Research news \\
\hline \hline ArticleFirstPage & $:$ & 1 \\
\hline \hline ArticleLastPage & $:$ & 2 \\
\hline \hline & $:$ & RegistrationDate : 2000-10-25 \\
ArticleHistory & $:$ & OnlineDate $\quad 2000-10-25$ \\
\hline \hline ArticleCopyright & $:$ & BioMed Central Ltd2000 \\
\hline \hline ArticleGrants & $:$ & \\
\hline \hline ArticleContext & $:$ & 130591111 \\
\hline \hline
\end{tabular}




\section{Jonathan B Weitzman}

Email: jonathanweitzman@hotmail.com

The regulation of gene expression is achieved by the functional interplay between factors that can remodel compacted chromatin and transcription factors that bind to specific DNA sequences. In the October Genes and Development Kadam et al. use recombinant proteins to show a direct physical interaction between transcription factors and the remodelling machinery in vitro (Genes Dev 2000, 14:2441-2451). Transcriptional regulation of the human $\beta$-globin promoter requires both the ELKF erythroid transcription factor and the SWI/SNF chromatin remodelling complex. Kadam et al. show that the ELKF zinc finger DNA-binding domain interacts with two SWI/SNF subunits (BAF155 and the ATPase BRG1). This interaction is necessary and sufficient for targeted chromatin remodelling and transcriptional activation of the $\beta$-globin promoter. The selectivity of the SWI/SNF-zinc finger interaction offers a mechanism for regulating specific subsets of genes by the chromatin remodelling machinery.

\section{References}

1. Genes and Development, [http://www.genesdev.org]

2. A SWI/SNF-related chromatin remodeling complex, E-RC1, is required for tissue-specific transcriptional regulation by EKLF in vitro.

3. ATP-dependent chromatin remodelling: SWI/SNF and Co. are on the job.

This PDF file was created after publication. 